\title{
Sero-prevalence of West Nile virus in Wild Birds in Bangladesh
}

\author{
Ausraful Islam ${ }^{1}$, Mohammad Enayet Hossain ${ }^{1}$, Mohammed Rahman ${ }^{1}$, Ariful Islam², \\ Asadur Rahman ${ }^{1}$, Suman Paul ${ }^{3}$, Parviez Hosseini ${ }^{2}$, and Nord Zeidner ${ }^{1}$ \\ ${ }^{1}$ icddr,b \\ ${ }^{2}$ EcoHealth Alliance \\ ${ }^{3}$ International Centre for Diarrheal Diseases Research, Bangladesh
}

August 10, 2020

\begin{abstract}
In this report we reported the sero-prevalence of West Nile virus among the resident and migratory wild birds from different locations of Bangladesh. 48 birds (48/888, 5.4\%, CI 0.04-0.07) were found sero-positive for WNV antibody.
\end{abstract}

\section{Hosted file}

Rajib_WNV_Wild birds_Manuscript_4th draft_10 August 20.doc available at https://authorea. com/users/349995/articles/474956-sero-prevalence-of-west-nile-virus-in-wild-birds-inbangladesh 